III. On some new species of Musci and Hepaticæ in the Herbarium of Sir W. J. Hooker, collected in tropical Africa, chiefly by the late Dr. Vogel and Mr. Barter. By William Mitten, A.L.S.

Read March 15th and June 21 st, 1860.

\title{
LePTotrichuv, Hampe.
}

L. ximidulum. Dioicum, gracillimum, humile; foliis erecto-patentibus e basi latiore sensim angustatis lanceolatis obtusiusculis integerrimis, nervo ubique a pagina distincto percurrente, cellulis basi infima majoribus oblongis inde angustis mollibus ; perichætialibus obtusioribus; theca in pedunculo trilineari gracillimo luteo erecta, late ovali, ore parvo, operculo subrecte subulato, peristomio dentibus parvis rubris rugulosis solidis, annulo lato composito trigono; planta mascula ramis brevibus floribus gemmiformibus terminatis.-L. exiguo simile.

Hab. On the earth. River Niger (Burter).

More slender than L. exiguum $=$ Wiessia exigua, Schw.=Dicranum xanthodon, Hook., inhabiting the West Indies and South America, and with more shining pale-green leaves.

TAB. V. fig. 1. 1. Plant (of the natural size); 2. a leaf, 3. the capsule, 4. the same after the fall of the operculum, 5. a portion of the peristome, and 6. a fragment of the annulus seen transversely (all magnified).

Strereodon, Bridel; Mitten, Musc. Ind. Orient. in Linn. Journ. Bot. Suppl. vol. i. p. 92.

S. Barteri, Mitten. Monoicus; foliis imbricatis late ovatis brevi-apiculatis concavis, margine (sicco) recurvo integerrimo, nervis binis brevissimis, cellulis alaribus pluribus quadratis viridibus, superioribus elongatis angustis; perichætio magno; foliis c basi ovata convoluta lanceolatis, internis erectis, paraphysibus exsertis; theca in pedunculo brevi luteo perichætium paululo superante ovali, peristomio dentibus_—? - Habitu $S$. longiseti, sed gracilior.

Hab. On trees in deep ravines. Nupe; River Niger (Barter, 1422).

Pale yellowish green, shining. Remarkable on account of its very short seta; in other respects closely agreeing in structure with S. longisetus = Neckera lonyiseta, Hook.

TAB. V. fig. 2. 1. Plant (of the natural size); 2. a leaf; 3. perichætium, male flower, and capsule (magnified).

Stereophyluum, Mitten, Musc. Ind. Orient. l. c. p. 117.

S. Nitens, Mitten. Monoicum; foliis elliptico-lingulatis basi contractis apice subacutis, nervo tenui medio evanido, marginibus superne subserratis, cellulis basi ad angulos quadratis inde ad apicem elongatis angustis parietibus crassis; perichætialibus parvis ovatis acuminatis parce serrulatis; theca in pedunculo gracili rubro parva ovali inclinata horizontalive, operculo brevi-rostrato, peristomio interno processibus longitudine 
dentes æquantibus in membrana ad tertiam partem longitudinis dentium exserta.Habitu staturaque $S$. radiculosi.

Hab. On decayed wood, Fernando Po (Barter).

Very nearly resembling S.radiculosum =Hookeria radiculosa, Hook. Musc. Exot. t. 51 ; but with leaves of a more equal width above and below the middle, and contracted at the base, the margin slightly serrulate, and the upper cells elongate. S.schistocalyx (Hypnum), C. Müller, has shorter leaves, more sharpened above, and with the upper cells nearly round.

ГАв. V. fig. 3. 1. Plant (of the natural size); 2. a leaf; 3. capsule; 4. perichætium and male flower; and 5 . a portion of the peristome (all magnified).

S. rivulare, Mitten. Ramis elongatis; foliis subcompressis ovato-lingulatis acutis basi contractis, nervo crasso paulo infra apicem evanido, marginibus superne erosis; cellulis superioribus minutis ovalibus obscuriusculis, basi brevioribus subquadratis. -S. radiculoso robustius.

$H a b$. On rocks in small rivulets at the bottoms of ravines. Nupe; River Niger (Barter, 1420).

In the firmer substance of its leaves allied to S. radiculosum, but a larger moss, with leaves more narrowed below, and more acute at their apices.

TA B. V. fig. 4. 1. Plant (of the natural size); 2. a leaf (magnified).

NeCKera, Hedw.

N. Foveolata, Mitten. Monoica; foliis perichætialibus inferioribus parvis apicibus patulis, interioribus magnis latis ellipticis, vaginantibus, acumine elongato patulo; theca ovali-cylindracea brevi-pedicellata immersa, operculo acuminato-rostrato, calyptra mitriformi vel uno latere fissa ramentis obtecta. $-N$. undulatce simillima.

Pilotrichum undulatum, Beauv. Prodr.

Hab. Afrique (Beauvais in Hb. Hooker.).

Very closely resembling $N$. undulata; but its perichætium entirely different, the ramenta (i.e. leaf-like paraphyses) being absent. According to a specimen marked Daltonia? (Neckera) undulata, from the herbarium of Dr. W. Arnott, this species is found also at Rio de Janeiro.

TAB. V. fig. 5. 1. Plant (of the natural size) ; 2. a leaf ; 3. perichæetium, capsule, and male flower (all magnified).

N. Flagellacea, Mitten. Caule primario repente, ramis arcuatis prolifero-ramosis pinnatis bipinnatisve filicinis planis compressis, ramulis apicem versus decrescentibus, sæpe in filum elongatum productis; foliis in caulis parte stipitiformi erectis appressis ovatis acuminatis subenerviis, superioribus lateralibus, caulinis ramulinisque divaricatis latissime ovatis asymmetricis obtusiusculis obtusisque apiculo parvo terminatis, marginibus ubique crenulatis, nervo supra medium desinente; cellulis inferioribus elongatis angustis, superioribus rotundatis minutis firmis.

$H_{r i b}$. River Niger (Barter).

In size and appearance resembling Neckera Korthalsiana, Dzy. et Molk. Bryol. Surinam. t. ix.; but its branches more regularly pinnate, and its leaves shorter, with a different areolation.

TAB. V. fig. 6. 1. A branch (of the natural size); 2. a lateral leaf from the middle of the branch, 3. a leaf from the ramuli (both magnified). 
Leskea, Hedw.

L. subfalcata, Mitten. Monoica; foliis caulinis hastato-subulatis caulem vestitum latitudine æquantibus, e basi patula erectis, marginibus minutissime crenulatis subintegerrimis, nervo valido in apice evanido, cellulis minutis rotundatis obscuriusculis; rameis ramulinisque subfalcatis patenti-incurvis compressis ligulato-lanceolatis, apicibus latis subacutis, nervo pallido sub apice evanido, marginibus minutissime crenulatis, dorso minute papiliosis; perichætialibus e basi ovali longe subulatis attenuatis integerrimis, nervo percurrente, cellulis elongatis pellucidis; theca in pedunculo rubro asperrimo.-L. grate simillima.

Hab. Moist rocks. Onitscha; River Niger (Barter, 1424).

Closely resembling L.grata, which was also gathered by Mr. Barter, but distinguished by the leaves of its ramuli being ligulate and not ovate, and by its entire perichætial leaves.

'TAB. V. fig. 7. 1. Plant (of the natural size); 2. a cauline leaf, 3. a leaf from the branches, 4. perichætium and male flower (magnified).

L. Nigeriana, Mitten. Monoica synoicave, caule foliolis vestito; foliis patentibus hastatoovatis acutis, nervo percurrente, marginibus minute crenulatis, cellulis rotundatis minutis obscuris papillosis; rameis divergentibus complanatis parum asymmetricis ovato-lanceolatis acutis, nervo sub apice evanido, marginibus crenulatis; perichætialibus erectis, e basi lata ovata longe (interdum subito) in subulam contractis, angulis paucis crenatis integerrimisve; theca in pedunculo elongato rubro asperrimo ovali horizontali cernuave, operculo subulato æquilongo ; peristomio externo dentibus valde trabeculatis, interno processibus subsolidis ciliis in unum coalitis æquilongis interpositis.-L. grate similis.

$H a b$. River Niger $($ Vogel $)$.

Resembling very nearly $L$. grata $=$ Hypnum gratum, Beauv.; but its branches more generally simple, cauline leaves not incurved from a patent base, those of the ramuli longer, divergent, and very much compressed, the perichætial leaves longer and not lacerate. From $L$. subfalcata it differs in the form of its cauline, and less ligulate ramuline leaves.

ТАв. V. fig. 8. 1. Plant (of the natural size); 2. a leaf from the stem, 3. a leaf from the branches, 4. a perichætial leaf, 5. capsule (magnified).

Callicostella, Mitten, Musc. Ind. Orient. l. c. p. 136.

C. Africana, Mitten. Synoica, habitu staturaque C. Merkelii; foliis in series denas dispositis compressis, marginibus e medio ad apicem argute serrulatis, nervis binis ad apicem percurrentibus ibique dorso serrulatis papillosis; seriebus tribus dorsalibus reliquis dimidio fere brevioribus erecto-patentibus appressis ovatis obtusis breviacuminatis, cellulis parvis abbreviatis fere rotundatis subobscuris ; seriebus lateralibus utrinque binis patenti-divergentibus e basi ovata uno latere inflexo-lingulatis obtusis apiculo brevi semitorto, cellulis superioribus oblongis, inferioribus laxioribus prosenchymaticis ; serie ventrali media cauli parallela appressaque ovato-lanceolatis breviacuminatis, cellulis laxis prosenchymaticis fere lævibus; perichætialibus patentibus e basi ovata in acumen lanceolatum angustatis; theca in pedunculo elongato flex- 
uoso rubro lævi apice (sicco) ruguloso ovali cernua; operculo subulato æquilongro; peristomio satis magno, dentibus medio linea pallidiore notatis valde trabeculatis crassis, interno processibus paulo longioribus solidis in membrana ad tertiam partem dentium longitudinis producta; calyptra superne scabra.

Hab. River Niger (Vogel); Nupe (Barter).

Leaves narrower than in any of the described species; seta smooth below, appearing slightly rough in the upper part when dry.

TA в. V. fig. 9. 1. Plant (natural size); 2. leaves, a. lateral, b. dorsal, $c$. ventral; 3. perichætial leaf, 4. the capsule, 5. calyptra (all magnified).

Fissidens, Hedw.

F. Vogeliants, Mitten. Monoicus, caule brevi; foliis patentibus elongate lanceolatis siccitate vix mutatis ubique tenuiter marginatis, lamina vera ultra medium producta, nervo obscuro percurrente, cellulis distinctis iis laminæ apicalis diametro circiter $\frac{1}{2000}$ uncix mensura; theca in pedunculo gracillimo quadrilineari suberecta ovali, operculo subulato æquilongo, peristomio generis, flore masculo gemmiformi ad pedem. rami fœminei.

Hab. River Niger (Vogel).

A small species agreeing in size and habit with the Javan $F$. Zollingeri, but with leaves of a firmer substance, of an obscure olive-brown colour.

TAB. V. fig. 10. 1. Plant (natural size); 2. the same, and 3. a leaf (magnified).

F. opacrfolius, Mitten. Monoicus, caule brevi; foliis patentibus late lanceolatis acutis siccitate non mutatis, lamina vera ad medium producta subinæquali crassiuscule hyalino-marginata, lamina apicali latiuscula dorsalique tenuiter crenata, cellulis opacis obscuris, nervo pellucido luteo percurrente; theca in pedunculo bilineari ovali erecta, operculo subulato, peristomio generis, calyptra basi integra papillosa, floribus masculis gemmiformibus in foliorum caulinorum axillis reconditis.

Hab. River Niger (Vogel); Natal (Guenzius).

The opaque rather broad leaves, pellucid nerve, and strongly margined border of the true leaf distinguish this species from its allies. The calyptra resembles that of $F$. serratus from the Nilgiri Mountains.

TAв. V. fig. 11. 1. Plant (natural size); 2. the same, 3. a leaf, 4. calyptra (all magnified).

F. Ramulosus, Mitten. Dioicus? caule fertili brevi, ramis gracilioribus e basi egredientibus

- ramoso; foliis patentibus siccitate crispatis lanceolatis immarginatis, lamina vera ad medium producta apice subinæquali, nervo subpellucido percurrente, marginibus ubique tenuiter crenatis, cellulis minutis obscuris diametro $\frac{1}{4000}$ unciæ metientibus; theca in pedunculo trilineari gracillimo ovali erecta, operculo subulato, peristomio generis, calyptra basi integra lævi.

Hab. River Niger (Vogel).

Allied to F. elegans, Schw., but with a different habit. From F. opacifolius it differs in the absence of margin to the true leaves, as well as in their form and in the inflorescence, and also in the smooth calyptra.

ТАв. V. fig. 12. 1. Plant (natural size); 2. the same, 3. leaf, 4. calyptra (magnified). 
F. scrophyluds, Mitten. Monoicus, statura F. bryoidis; foliis patentibus oblongo-ellipticis latiusculis acutis, nervo pallido percurrente, lamina vera ad medium producta, omnibus laminis immarginatis tenuiter crenulatis, cellulis opacis; theca in pedunculo gracillimo ovali subæquali siccitate urceolata; flore masculo in apicibus ramorum.

Hab. Interior of Africa (Mungo Park).

Nearly allied to $F$. opacifolius, but the lamina vera is without the hyaline margin, and the inflorescence and capsule are different; it is also allied to $F$. Hornschuchii, Mont., and agrees with it in inflorescence, but the structure of the leaves is not the same.

TAB. VI. fig. 13. 1. Plant (natural size); 2. the same, 3. leaf (magnified).

F. curvifolius, Mitten. Dioicus? humilis, gracilis ; foliis plurijugis patentibus falcatocurvatis elliptico-lanceolatis, nervo pallidiore sed obscuro percurrente, lamina vera supra medium producta, lamina dorsali in caulem decurrente, omnibus laminis immarginatis tenuissime crenulatis integerrimisve, cellulis minutis obscuris diametro circiter $\frac{1}{3000}-\frac{1}{4000}$ unciæ mensura; theca in pedunculo gracili luteo? ovali inclinata, operculo subulato.

Hab. On the earth. Niger (Vogel).

Almost intermediate between the species which, without any margination to the apical lamina, have their leaves entire or crenulate; in the present the crenulation is indistinct, but the cells, although obscure, are distinguishable, and, together with the form and flexure of the leaves and inclined capsule, distinguish it from its allies.

TAB. VI. fig. 14. 1. Plant (natural size); 2. the same, 3. leaf (magnified).

F. ripensis, Mitten. Crespitosus, caule elongato ; foliis patentibus siccitate parum mutatis ligulato-lanceolatis acutis, nervo percurrente, lamina vera ad medium producta apice inæquali, lamina dorsali basi contracta, omnibus laminis immarginatis tenuiter crenulatis, cellulis distinctis diametro circiter $\frac{1}{200} \overline{0}$ unciæ metientibus.

Hab. On moist rocks. Niger (Barter).

This appears to be the largest known species belonging to the group with immarginate crenulate leaves, and is easily known by its distinct and pellucid areolation.

TAB. VI. fig. 15. 1. Plant (natural size); 2. portion of stem and leaves (magnified).

F. GLADIolus, Mitten. Dioicus? humillimus, parvulus; foliis circiter trijugis anguste lanceolatis sensim angustatis acutis, nervo intensius colorato percurrente, lamina vera ad medium producta, omnibus laminis immarginatis integerrimis, cellulis elongatis laxiusculis distinctis; foliis perichætialibus lamina vera apice inæequali, uno latero libero; theea in pedunculo gracillimo ovali inclinata, operculo brevirostrato.

Hab. Interior of Africa (Mungo Park).

This minute slender species is remarkable for its narrow, loosely areolate leaves. The whole plants are about three lines high.

TAB. VI. fig. 16. 1. Plant (natural size); 2. the same, 3. leaf (magnified). 
F. Porrectus, Mitten. Cæspitosus, caule elongato rubro; foliis patentibus siccitate immutatis elliptico-lanceolatis acuminatis, acumine ad caulis apicem leniter curvato, nervo percurrente, lamina vera ad medium producta, omnibus laminis margine obscuriore subopaco limbatis, cellulis distinctis diametro circiter $\frac{-1}{200}$ uncixe metientibus.

$H a b$. On moist rocks. Niger (Barter).

Growing in large patches, of a fresh green colour, here and there tinged with red, slightly glossy, in appearance nearly resembling $F$. rigidulus, H. f. et $W$., but with a margin, although distinctly cartilaginous, like the nerve obscure. The fructification is evidently terminal, from the presence of archegonia on a feir of the stems; but the perichætial leaves have no difference in form from the cauline.

TA 3. VI. fig. 17. 1. Plant (natural size); 2. portion of the stem and leaves (magnified).

F. FuACCIDUs, Mitten. Dioicus? statura F. palmati; foliis patentibus flaccidis late elliptico-lanceolatis apice acutis, nervo debili sub apice evanido, lamina vera ad medium producta, omnibus laminis hyalino-marginatis ; cellulis oblongis longitudine circiter $\frac{1}{1000}$, latitudine $\frac{1}{2000}$ unciæ mensura, pellucidis; theca in pedunculo gracili rubro ovali erecta, operculo subulato.

$H a b$. On the earth. Niger (Vogel).

Similar to $F$. palmatus, Sw., but with an erect capsule and less acuminate leaves. From the other African species it is readily known by its lax areolation.

TA13. VI. fig. 18. 1. Plant (natural size); 2. the same, 3. leaf, 4. young calyptra (all magnified).

F. Parkir, Mitten. Dioicus? perpusillus; foliis 4 -5-jugis patentibus ambitu late elliptico-lanceolatis obtusiusculis, nervo concolori percurrente, lamina vera ultra medium producta, lamina dorsali supra basin evanescente, omnibus laminis immarginatis integerrimis, cellulis minutis subobscuris diametro circiter $\frac{1}{5000}$ unciæ metientibus; foliis perichætialibus lateribus laminæ veræ inæqualibus, uno latere apice libero in nervum ascendente; theca in pedunculo brevi erecta æquali brevi ovali.

Hab. Interior of Africa (Mungo Park).

Yellowish green. Scarcely tro lines high. The seta of the same length as the perichætial leaves. This is probably the species gathered by Park when reduced to a deplorable state, and the contemplation of which so revived him as to enable him to proceed and obtain succour. It will be easily seen that it is remote from the European $F$. bryoides, to which it was formerly referred, and that it is more nearly allied to $F$. asplenioides, Sw., and F. obtusifolius, Wils.

TAB. VI. fig. 19. 1. Plant (natural size); 2. the same, 3. leaf (magnified).

\section{Pogonatum, Brid.}

P. Flexuosum, Mitten. Foliis e basi latiore erecta angustatis longe loriformi-lanceolatis latiusculis acutis patentibus, siccitate incurvis falcatisve rigidis, nervo dorso superne serrato, margine a basi ubi angustare incepit serrato, pagina superiore fere toto lamellis brevissimis vix conspicuis obtecta; floribus masculis foliis internis brevioribus latioribusque.-P. convoluto simile.

Hab. Niger (Barter). 
Intermediate between $P$. convolutum, Brid. and $P$. macrophyllum, Dzy. et Molk. In the firm substance of its leaves it agrees with the first, but their outline is more nearly that of the last-named species. The specimens vary from 4 to 5 inches in height.

TAB. VI. fig. 20. 1. Plant (natural size); 2. leaf (magnified).

Plagiochila, Nees et Mont.

P. NeCKerotdea, Mitten. Caule repente, ramis iterato dichotomis; foliis basi imbricatis divaricatis ovato-lanceolatis apice obtusis bidentatisve, margine dorsali recurvo integerrimo, ventrali apiceque parce dentatis, cellulis parvis oblongis interstitiis angustis ; involucralibus dentibus spinosioribus; perianthio obovato truncato compresso, labiis spinoso-dentatis.

Hab. On trees. Niger (Barter).

Very nearly resembling $P$. abrupta, L. et L., but with leaves composed of cells very much smaller and with thin walls. From P. disticha, L. et L. (gathered also by Barter), it is immediately distinguished by the plants being scarcely altered when dry, and the different form of the perianth. The more robust stems have much the appearance of $P$. cristata $\mathrm{Sw}$., but they are far smaller and the leaves are not cristatebehind.

TAB. VI. fig. 21. 1. Plant (natural size); 2. leaves, 3. perianth and involucral leaf (magnified).

\section{Chinoscrphus, Corda.}

C. oblongrfolius, Mitten. Caule repente parce ramoso ; foliis horizontalibus divergentibus oblongis parallelogrammaticis apice integris sinuatis uni- bi- tridenticulatis, cellulis interstitiis obscuris grossiusculis, amphigastriis parvis bipartitis laciniis extrorsum unidentatis, uno latere in folium anguste decurrente; perianthio (juvenili) laciniis dentatis.

Hab. On moist rocks, Onitscha; and on oil palms, Brass; Niger (Barter).

Dark brown. In size and habit resembling the Oriental $C$. argutus, Nees, but with leaves of a different substance and truncate at their apices.

Tа в. VI. fig. 22. 1. Plant (natural size); 2. portion of stem with leaves and amphigastria; 3. the perianth spread open.

Iepidozia, Nees, Ldbg. et Gottsche.

L. succida, Mitten. Caule procumbente inordinate pinnato, ramis decurvis flagelliformiattenuatis ; foliis caulinis erecto-patentibus caulem latitudine vix superantibus ovalioblongis, apice inæqualiter brevi bi- tri- quadridentatis, amphigastriis parvis quadripartitis; rameis majoribus imbricatis rhomboideo-ovalibus, apice superiore sinu parvo bidentatis, cæteroquin integerrimis, amphigastriis parvis trifidis, cellulis oblongis magnis pellucidis.

Hab. On moist rocks. Nupe; Niger (Barter).

Somewhat resembling $L$. Wallichiana, Gottsche, and L. centipes, Taylor, but remarkable for the rhomboidal subentire leaves of its branches.

TAB. VI. fig. 23. 1. Plant (natural size); 2. a portion of the stem, 3. portion of a branch with leaves (magnified).

vol. XXIII. 
Lejeunia, Gottsche et Ldbg.

(Phragmicoma.)

L. EXCAVATA, Mitten. Ramis cæspitosis dichotome ramosis; foliis divaricatis imbricatis rotundatis, apice decurvis sinu parvo minute bidentatis, basi lobulo oblongo unidentato complicato, amphigastriis appressis orbiculatis foliis dimidio minoribus, cellulis parvis rotundatis; involucralibus conformibus, lobulis minoribus; perianthio oblongo obtuso appresso, dorso concavo, ventre convexo, lævi.

Hab. On trees. Niger (Barter).

In size and appearance resembling Omphalanthus geminiforus, Nees, but more nearly allied to Phraymicoma Mackaii, Dumort.

TAB. VI. fig. 24. 1. Plant (natural size); 2. portion of stem with leaves and amphigastria; 3. perianth and involucral leaves; 4 . transverse section of perianth.

\section{(Acrogonia.)}

L. AstroIdea, Mitten. Epiphylla, maculas astroideas formans; foliis patentibus rhomboideis integerrimis, angulo externo superiore acuminato, inferiore rotundato lobulo minuto inflexo; cellulis heteromorphis, minoribus rotundatis interstitiis crassiusculis, majoribus 3-5-seriatim inordinatimve per folium dispositis, una majore semper in angulo inferiore partim a lobulo obtecta; amphigastriis alternis ad basin in lacinias duas patentes subulatas divisis.

Hab. On living leaves. Niger (Burter).

Loosely appressed to the surface of the leaves, in company with a species of Radula which, in so far as it can be judged of in a barren state, does not differ from $R$. Grevilleana, Taylor. This Lejeunia evidently belongs to the same curious section as $L$. Krausiana and a number of other tropical species, for the most part growing on the surface of leaves, and producing a turbinate pentagonal perianth, the angles being more or less produced into a horn-like point.

TAB. VI. fig. 25. 1. Plant (natural size); 2. portion of stem with leaves and amphigastrium (magnified).

Anthoceros, Micheli.

(Notothylas, Sullivant.)

A. DECURVus, Mitten. Fronde pusilla planiuscula ambitu radiatim lobata, lobis sinuatis dentatisque, involucris brevibus decurvis lacinulis sparsis vestitis, capsula inclusa subsessili, sporis luteis, columella nulla.

Hab. On the earth with a Riccia. Niger (Barter).

Resembling Notothylas valvata, Sullivant (in 'Memoirs of the American Academy of Arte and Sciences,' vol. iii. new series, pl. 4); but, in proportion to the size of the frond, the involucra are much smaller. The capsule is not protruded in the few specimens examined, but seems entirely enclosed in the involucre; no trace of the suture or columella was visible. Anthoceros Brentelii, Gottsche, found in the West Indies, is another species of this curious group; its capsule is protruded, and opens with a suture.

TAв. VI. fig. 26. 1. Plant (natural size); 2. a portion with an involucre, 3. spores (magnified). 


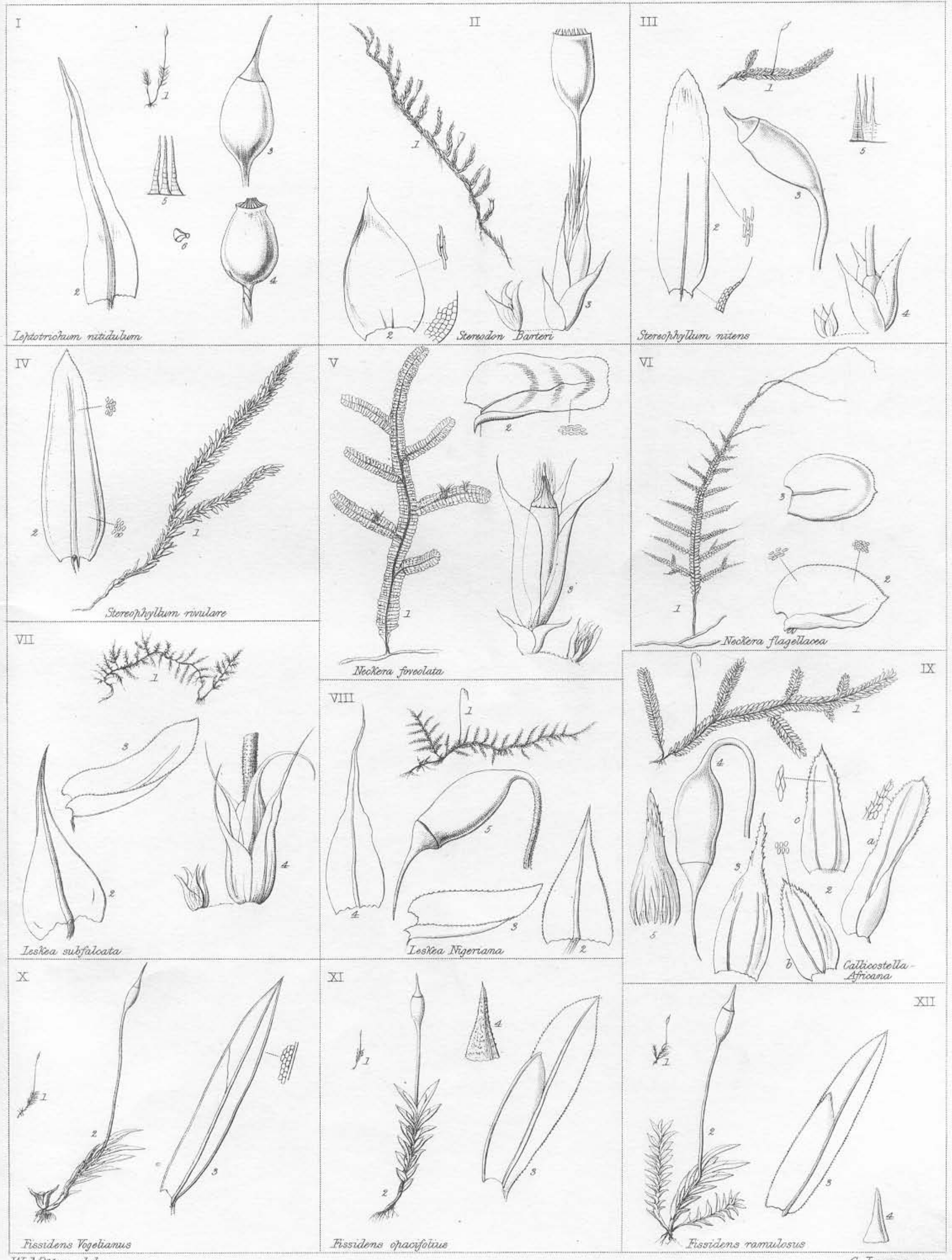

W. Mitten del. 


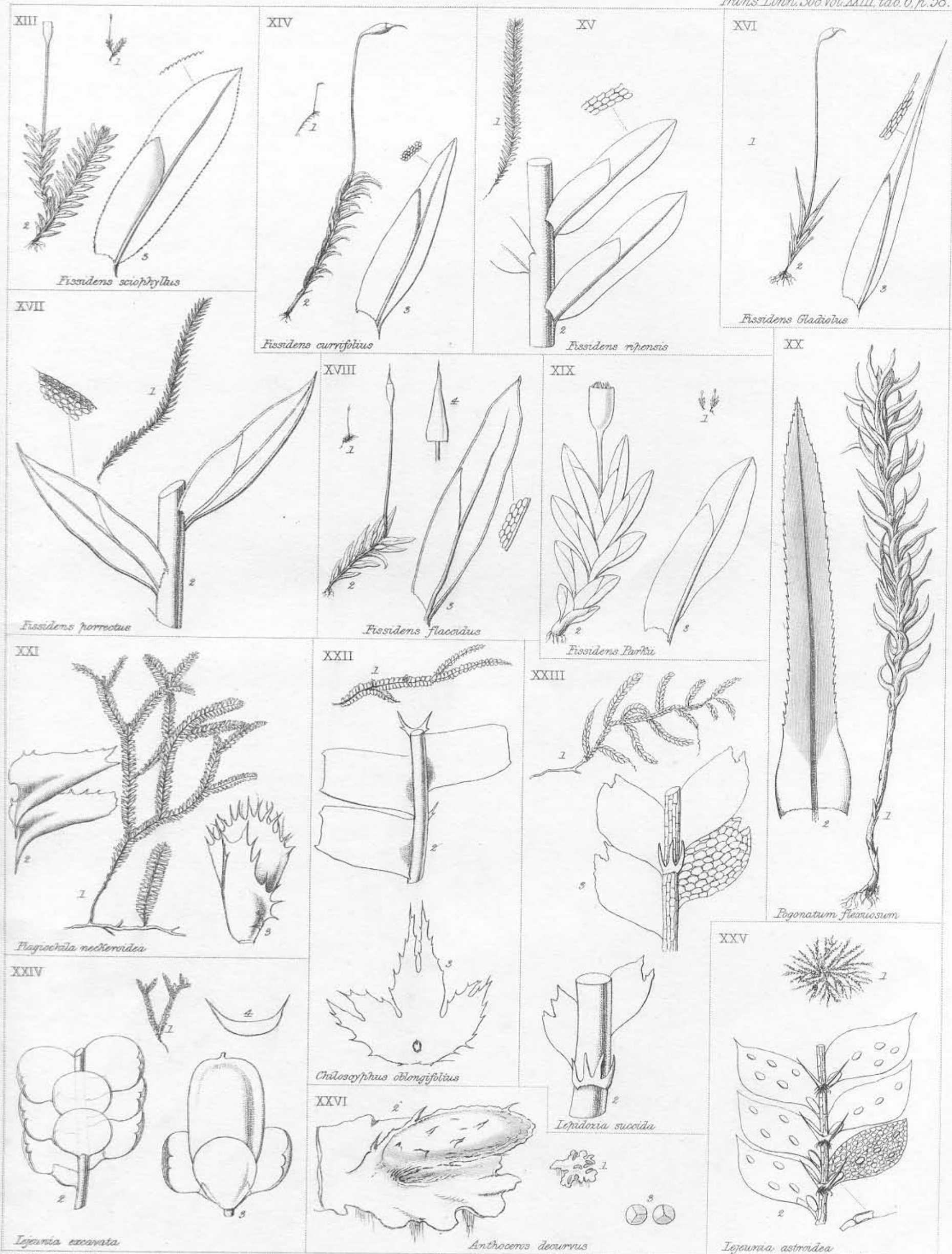

W. Mrtean, del. 